\title{
Erratum to: Understanding and eliminating iron interference in colorimetric nitrate and nitrite analysis
}

\author{
Benjamin P. Colman • Joshua P. Schimel
}

Published online: 23 April 2010

(C) Springer Science+Business Media B.V. 2010

\section{Erratum to: Environ Monit Assess}

\section{DOI 10.1007/s10661-009-0974-x}

1. In the article, "Understanding and eliminating iron interference in colorimetric nitrate and nitrite analysis," (DOI number 10.1007/ s10661-009-0974-x) a typesetting error was made, and the co-author was mistakenly left out. The authors' names should be listed as:

Benjamin P. Colman and Joshua P. Schimel
2. In addition, the chemical structure for the final azo dye in Fig. 1 had an error. The corrected figure is shown here.

Fig. 1 Reaction scheme for colorimetric analysis of $\mathrm{NO}_{2}^{-}$<smiles>N#[N+]c1ccc(S(N)(=O)=O)cc1</smiles>

The online version of the original article can be found at: http://dx.doi.org/10.1007/s10661-009-0974-x.

B. P. Colman $(\varangle) \cdot$ J. P. Schimel University of California, Santa Barbara, CA, USA e-mail: colmanb@gmail.com 